ISTIGHNA, Vol. 2, No 2, Juli 2019 P-ISSN 1979-2824 E-ISSN 2655-8459

Homepage: http://e-journal.stit-islamic-village.ac.id/index.php/istighna

Minggusta Juliadarma

Pencegahan Kenakalan Anak Menurut Abdullah Nasih Ulwan

\title{
PENCEGAHAN KENAKALAN ANAK MENURUT ABDULLAH NASIH ULWAN
}

\author{
${ }^{1}$ Minggusta Juliadarma \\ Institut Agama Islam Negeri (IAIN) Ternate \\ email: minggustajuliadarma@iain-ternate.ac.id
}

\begin{abstract}
The concept of preventing child delinquency according to Nāhịh 'Ulwān is a concept of preventive action that can suppress the onset of delinquency and behavior deviation in children. Some parties who take responsibility in holding their role in preventing juvenile delinquency, namely parents, society, and the State. This social institution circle is interrelated and can determine the direction of children's behavior in the future. Broadly speaking, Nāṣih 'Ulwān's view of preventing child delinquency can be sought by maximizing several methods, namely Supervision of the negative impact of mass media on children by methods of planting Islamic principles, Active role of parents in applying the stages of sexual education for children, Creating relationships harmonious relationship between the father and mother with the fulfillment of their respective rights and obligations, Supervising the social behavior of children with the authoritative Parenting method, guaranteeing the state of the economic welfare of its citizens, parents behaving softly and avoiding bad treatment of children, filling free time children with useful means of amaliyat, and cooperation of parents in paying attention to their children's education.
\end{abstract}

\section{Keywords: Juvenile Delinquency; Nasih Ulwan}

\begin{abstract}
Abstrak: Konsep pencegahan kenakalan anak menurut Nāṣih 'Ulwān merupakan sebuah konsep tindakan preventif yang dapat menekan timbulnya kenakalan dan penyimpangan perilaku pada anak. Beberapa pihak yang ikut bertanggung jawab dalam memegang peranannya dalam mencegah kenakalan anak, yaitu orang tua, masyarakat, dan Negara. lingkaran pranata sosial inilah yang saling berkaitan dan dapat menentukan arah perilaku anak ke depannya. Secara garis besar, pandangan Nāṣih 'Ulwān tentang pencegahan kenakalan anak dapat diupayakan dengan memaksimalkan bebarapa metode, yaitu Pengawasan terhadap dampak negatif media massa pada anak dengan metode penanaman prinsip-prinsip Islam, Peran aktif orang tua dalam mengaplikasikan tahapan pendidikan seksual bagi anak, Menciptakan hubungan yang harmonis antara bapak dan ibu dengan pemenuhan hak dan kewajiban masing-masing, Melakukan pengawasan terhadap tingkah laku sosial anak dengan metode authoritative Parenting, Jaminan negara terhadap kesejahteraan ekonomi warganya, Orang tua berlaku lemah lembut dan menghindari perlakuan yang buruk terhadap anak, Mengisi waktu luang anak dengan sarana-sarana 'amaliyat yang bermanfaat, dan Kerja sama orang tua dalam memperhatikan pendidikan anaknya.
\end{abstract}

Kata Kunci: Kenakalan Anak; Nasih Ulwan 
ISTIGHNA, Vol. 2, No 2, Juli 2019 P-ISSN 1979-2824 E-ISSN 2655-8459

Homepage: http://e-journal.stit-islamic-village.ac.id/index.php/istighna

Minggusta Juliadarma

Pencegahan Kenakalan Anak Menurut Abdullah Nasih Ulwan

\section{A. PENDAHULUAN}

Anak merupakan amanah bagi orang tua, maka mereka harus memberikan proteksi pada kalbunya yang masih bersih. Jika anak dibiasakan untuk melakukan kebaikan, niscaya dia akan tumbuh menjadi baik. Sebaliknya, jika dibiasakan dengan keburukan serta ditelantarkan seperti hewan ternak, niscaya dia akan menjadi orang yang tidak bermoral. ${ }^{1}$

Dewasa ini banyak sekali tantangan yang harus dihadapi dalam pendidikan anak, tidak hanya bagi orang tua, tetapi juga bagi lembaga-lembaga pendidikan dan Negara dalam menyiapkan sistem pendidikan yang komprehensif dan ideal bagi anak, di tengah-tengah realitas kehidupan yang semakin memburamkan pendidikan anak. Akan tetapi ternyata tantangan-tantangan tersebut seakan menjadi bola salju yang semakin membesar sehingga berdampak pada aspek psikis anak, maka dampaknya adalah timbulnya kenakalan pada anak.

Banyak sekali penyebab dan sarana yang bisa mengakibatkan terjadinya kenakalan pada anak. Rusaknya moralitas, pendidikan yang buruk di masyarakat dan kenyataan hidup yang pahit adalah beberapa pemicunya. Seandainya para pendidik tidak benar benar memikul tanggung jawab dan amanah ini, maka bisa dikhawatirkan anak-anak akan menjadi generasi yang bergelimang dosa dan generasi yang penuh penderitaan di masyarakat. ${ }^{2}$

Menurut Muhaimin Azzet, bentuk kenakalan anak seperti anak suka memberontak, suka mencuri, berbohong, meniru perilaku buruk, egois, pelit, suka membangkang, merokok, kecanduan bermain game, kecanduan pornografi dan malas beribadah. ${ }^{3}$

Bentuk kenakalan anak di atas tergolong bentuk kenakalan anak yang tergolong ringan, namun tidak jarang hal itu seringkali menjadi hambatan bagi pendidik dan orang tuanya. Bentuk kenakalan yang lebih besar tentunya akan terjadi jika bentuk kenakalan ringan tersebut tidak dapat dinetralisir oleh pendidik dan orang tua.

Menurut hasil penelitian yang diungkapkan oleh Paulus Hadisuprapto dalam bukunya, bahwa temuan penelitian menunjukkan bahwa dari 200 anak pelaku delinkuen/kenakalan dari dua kota di Jawa Tengah itu semuanya pelajar, berpendidikan SLTP (51 \%), SD (31\%), SMU (18\%), dan sisanya berumur di atas 18 tahun. Anak-anak tersebut berurusan dengan petugas hukum karena melakukan perbuatan yang termasuk kategori tindak pidana terhadap harta benda, badan/nyawa, perusakan terhadap fasilitas umum (vandalisme) dan di bidang lalu lintas.

Dari tindak pidana yang dilakukan oleh anak-anak berdasarkan penelitian tersebut sebagian besar tindak pidana perusakan fasilitas umum dan lalu lintas, sedangkan pelaku tindak pidana terhadap badan/nyawa hanya $6 \%$. Sedangkan jenis sanksi yang dijatuhkan pada mereka berupa sanksi pidana $(80 \%)$ dengan

\footnotetext{
${ }^{1}$ Jamaal Abdul Rahman, Tahapan Mendidik Anak; Teladan Rasulullah SAW (Bandung: Irsyad Baitus Salam, 2005), Hlm. 16

${ }^{2}$ Abdullah Nasih Ulwan, Tarbiyat al-Aulad fi al-Islam (Suriah: Daar al-Salaam, 1992), Hlm. 121

${ }^{3}$ Muhaimin Azzet, Buku Pintar Mengatasi Anak Nakal (Yogyakarta: Kata Hati, 2010), Hlm.
} 
ISTIGHNA, Vol. 2, No 2, Juli 2019 P-ISSN 1979-2824 E-ISSN 2655-8459

Homepage: http://e-journal.stit-islamic-village.ac.id/index.php/istighna

Minggusta Juliadarma

Pencegahan Kenakalan Anak Menurut Abdullah Nasih Ulwan

pidana penjara (62\%) sisanya (18\%) dijatuhi pidana bersyarat. Sementara jenis sanksi lainnya berupa sanksi tindakan $(20 \%)$ dengan mengembalikan anak itu pada orang tuanya ( $13 \%$ ), sisanya ( $7 \%$ ) dikenakan tindakan berupa penyerahan anak kepada Negara untuk di didik (anak negara). ${ }^{4}$

Beberapa pakar pendidikan mencoba menganalisis dan mengelaborasi terhadap persoalan kenakalan yang terjadi pada anak tersebut, salah satunya adalah Abdullah Nāṣiḥ 'Ulwān (selanjutnya Nāṣiḥ 'Ulwān). Menurutnya sebabsebab terjadinya kenakalan anak tidak dapat dipikul oleh anak seorang, akan tetapi ada pihak-pihak yang ikut memberikan kontribusi terjadinya penyimpangan pada anak ini, seperti keluarga, masyarakat, dan Negara. Ketiga elemen pembentuk pranata sosial tersebut ikut bertanggung jawab sebagai sebab terjadinya kenakalan anak.

Penelitian ini mencoba menganalisis pembahasan tentang bentuk-bentuk kenakalan anak, penyebab kenakalan pada anak dan cara pencegahannya menurut Nāṣiḥ 'Ulwān. Namun, Fokus penekanan dalam penelitian ini lebih pada pembahasan cara pencegahan kenakalan anak yang dianalisis dengan pendekatan ilmu pendidikan Islam, sedangkan pembahasan mengenai bentukbentuk kenakalan anak dan penyebab kenakalan anak pada penelitian ini sebatas untuk mengidentifikasi cara yang tepat dalam pencegahan kenakalan anak.

Kenakalan anak yang dimaksud dalam penelitian in adalah anak yang memiliki perilaku tidak sesuai dengan keinginan atau harapan orang tua yang berkesesuaian dengan nilai-nilai yang dianut oleh orang tua, keluarga, dan lingkungan. Untuk mendeteksi terjadinya kenakalan pada anak, harus terlebih dahulu diketahui pangkal penyebabnya dan bentuk kenakalannya, untuk kemudian dicari cara terbaik sebagai pencegahannya.

\section{B. METODE PENELITIAN}

Dalam penulisan penelitian ini, penulis menggunakan metode penelitian kepustakaan (library research) dengan mengelaborasi pemikiran Nasih Ulwan tentang pencegahan kenakalan anak yang terdapat di dalam beberapa karya tulisnya. Sedangkan pendekatan penelitian yang dipilih adalah pendekatan analisis deskriptif-kualitatif.

Sumber data pustaka yang dijadikan sumber acuan dalam penelitian ini menggunakan sumber data primer. Sumber data primer diambil dari karya-karya tulis asli yang disusun oleh Nasih Ulwan yang relevan dengan tema penelitian ini, diantaranya kitab Tarbiyat al-Aulad Fi al-Islam, Ilaa Kulli Abin Ghayuur Yu'min Billah, Hukm al-Islam Fi Wasaailil I'laam, Mas'uliyat al-Tarbiyat alJinsiyyat, al-Takaf al-Ijtima'I Fi al-Islaam, dan 'Aqabat al-Zawaj wa Turuq Muallajatih 'Ala Daui al-Islaam. Sedangkan sumber data sekunder berasal dari karya ilmiah seseorang yang membahas tentang karya Nasih Ulwan, namun untuk sementara ini penulis belum menemukannya.

Teknik pengumpulan data yang digunakan adalah teknik dokumentasi, yaitu dengan mengumpulkan data dari beberapa kitab karya Nasih Ulwan. Sedangkan teknik analisis data yang digunakan menggunakan analisis wacana, yaitu

${ }^{4}$ Paulus Hadisuprapto, Delinkusensi Anak; Pemahaman dan Penanggulangannya (Malang: Bayu Media Publishing, 2008), Hlm. 210 
ISTIGHNA, Vol. 2, No 2, Juli 2019 P-ISSN 1979-2824 E-ISSN 2655-8459

Homepage: http://e-journal.stit-islamic-village.ac.id/index.php/istighna

Minggusta Juliadarma

Pencegahan Kenakalan Anak Menurut Abdullah Nasih Ulwan

memandang teks sebagai satu kesatuan isi dan berhubungan dengan pemakaian bahasa. Bahasa pengantar yang bersumber dari data primer menggunakan bahasa arab. Selain karena minimnya karya beliau yang dialih bahasakan ke bahasa Indonesia (hanya Kitab Tarbiyat al-Aulad Fi al-Islam yang sudah dialih bahasakan ke bahasa Indonesia), penulis sengaja memakai kitab asli beliau untuk dianalisis semata-mata demi utuhnya proses elaborasi pemikiran beliau dari sumber aslinya, bukan dari penerjemahnya.

\section{HASIL DAN PEMBAHASAN}

\section{Pengertian Kenakalan Anak}

Berdasarkan penelusuran dari berbagai bukunya, didapati pengertian kenakalan anak secara etimologis menurut Nasih Ulwan, yaitu inhiraaf (menyimpang), Syaqawat (seserang yang berada dalam kesulitan), khalaa'iyat (terkekang), Suu' (keburukan), Syaar (kejelekan), jarimat (kriminal/kejahatan), fasaad (keji), inhilal (nakal).

Sedangkan secara terminologis, kenakalan menurut Nasih Ulwan adalah tindakan anarkhis dan merugikan orang lain yang dapat dikategorikan sebagai kejahatan karena melanggar undang-undang, dan berdampak pada kerusakan berat pada ahlaknya.

Dalam mendefinisikan beberapa indicator perilaku anak yang negatif (menurut pengertian etimologis), Nasih Ulwan sering menyandarkan beberapa indicator tersebut dengan istilah yang bermacam-macam, yaitu aulaad (anak), tifl/athfaal (anak), abnaa' (anak), muraahiq (remaja), syabaab (pemuda).

Dengan demikian, dari segi etimologis, Nasih Ulwan memiliki kecenderungan memilih istilah kenakalan anak, hal itu didasarkan pada realita yang ada di beberapa bukunya yang lebih dominan dengan penyebutan anak. Meskipun pada pembahasan tentang permasalahan seksual, memakai istilah remaja. Berkaitan dengan dua istilah tersebut, sebenarnya Nasih Ulwan masih memasukkan remaja ke dalam masa anakanak. Setidaknya hal itu dapat terlihat dari pernyataan beliau yang menyebutkan pemuda yang sudah baligh juga termasuk dalam kategori masa anak-anak.5 Sedangkan pemuda menurut perspektif gradualitaas perkembangan berada setingkat di atas dari masa remaja.

Istilah kenakalan anak dirasa memiliki makna sangat tajam dan memiliki konotasi negatif secara kejiwaan terhadap anak. Namun para ahli pendidikan lebih cenderung memakai istilah tersebut. Selain itu, istilah kenakalan anak merupakan istilah umum yang berlaku pada ranah internasional, yaitu istilah juvenile delinquency (kenakalan anak). ${ }^{6}$

\section{Bentuk-bentuk Kenakalan Anak}

Bentuk kenakalan anak menurut Nasih Ulwan yang tersebar di beberapa bukunya diantaranya adalah interaksi anak dengan hal-hal yang berbau

${ }^{5}$ Abdullah Nasih Ulwan, Mas'uliyat al-Tarbiyat al-Jinsiyyah (Suriah: Daar al-Salaam, 2010), Hlm. 5

${ }^{6}$ Kartini Kartono, Psikologi Anak (Psikologi Perkembangan) (Bandung: Mandar Maju, 1995), Hlm. 224 
ISTIGHNA, Vol. 2, No 2, Juli 2019 P-ISSN 1979-2824 E-ISSN 2655-8459

Homepage: http://e-journal.stit-islamic-village.ac.id/index.php/istighna

Minggusta Juliadarma

Pencegahan Kenakalan Anak Menurut Abdullah Nasih Ulwan

pornografi, ${ }^{7}$ membunuh, ${ }^{8}$ mencuri, ${ }^{9}$ berakhlak buruk, ${ }^{10}$ dan lemahnya akidah. ${ }^{11}$

Interaksi anak dengan hal-hal yang berbau pornografi, di dalamnya termasuk aktivitas anak berupa menyaksikan, membaca, dan mendengar hal-hal yang berkaitan dengan pengumbaran hasrat seksual mereka tidak pada tempatnya. Semua aktivitas tersebut dapat dijangkau anak melalui penyalahgunaan sarana media massa, seperti televisi, radio, Koran, majalah, bioskop, dan panggung kesenian.

Bentuk kenakalan anak lainnya adalah membunuh. Dalam hal ini, Nasih Ulwan berpendapat dalam kondisi tertentu, anak dapat membunuh orang lain, bahkan dapat membunuh dirinya sendiri. Tentu saja semua pihak sepakat bahwa aktivitas membunuh merupakan aktivitas yang lazim dilakukan orang dewasa. Namun disinilah kepekaan intelektual seorang Nasih Ulwan, menurut beliau aktivitas membunuh juga dapat dilakukan oleh anak-anak. Pemikiran tersebut tentunya dilatarbelakangi oleh aspek empiris beliau sebagai pakar pendidikan anak yang tidak terjebak pada fenomena umumyang lazim terjadi di masyarakat.

Nasih Ulwan juga mengklasifikasikan akhlak buruk sebagai salah satu bentuk kenakalan anak, karena dalam perspektif pendidikan islam, pada dasarnya anak yang memiliki akhlak buruk sangat rentan memiliki kebiasaan berkata kotor dan bisa melakukan tindak kekerasan. Bentuk kenakalan ini timbul sebagai reaksi balik terhadap pengalaman pribadi mereka dalam bersosialisasi di lingkungannya.

Pemikiran Nasih Ulwan tentang bentuk kenakalan anak tersebut berbeda dengan bentuk kenakalan anak yang disusun oleh pakar pendidikan anak selama ini. Perbedaannya terletak pada dampak yang ditimbulkan dari kenakalan anak tersebut. Jika Selama ini para ahli pendidikan merumuskan berbagai bentuk kenakalan anak, maka akan ditemukan bentuk kenakalan tersebut berdampak buruk pada orang lain, sehingga tindakan tersebut bisa melanggar norma hukum dan norma social. Namun menurut Nasih Ulwan, bentuk kenakalan anak tidak hanya berhenti pada tindakan melanggar norma hukum dan sosial saja, tetapi juga dapat melanggar norma agama. Oleh sebab itu, Nasih Ulwan memasukkan lemahnya akidah sebagai salah satu bentuk kenakalan anak.

\section{Sebab-sebab Terjadinya Kenakalan Anak}

Fenomena kenakalan anak tidak terjadi secara tiba-tiba, hal itu bisa terjadi karena ada beberapa hal yang melatarbelakanginya. Sebab-sebab terjadinya kenakalan anaktidak dapat dipikul oleh anak seorang, tetapi ada

${ }^{7}$ Abdullah Nasih Ulwan, Mas'uliyat al-Tarbiyat al-Jinsiyyah (Suriah: Daar al-Salaam, 2010), Hlm. 26

${ }^{8}$ Abdullah Nasih Ulwan, Tarbiyat al-Aulad fi al-Islam (Suriah: Daar al-Salaam, 1992), Hlm. 140

${ }^{9}$ Abdullah Nasih Ulwan, Tarbiyat al-Aulad fi al-Islam, Hlm. 135

${ }^{10}$ Abdullah Nasih Ulwan, Tarbiyat al-Aulad fi al-Islam, Hlm. 140

${ }^{11}$ Abdullah Nasih Ulwan, Hukm al-Islam Fi Wasaail al-I'laam (Suriah: Daar al-Salaam, 2001), Hlm. 6 
ISTIGHNA, Vol. 2, No 2, Juli 2019 P-ISSN 1979-2824 E-ISSN 2655-8459

Homepage: http://e-journal.stit-islamic-village.ac.id/index.php/istighna

Minggusta Juliadarma

Pencegahan Kenakalan Anak Menurut Abdullah Nasih Ulwan

pihak-pihak yang ikut memberikan kontribusi terjadinya penyimpangan pada anak ini, seperti keluarga, masyarakat, bahkan Negara. Ketiga elemen pembentuk pranata sosial tersebut ikut bertanggung jawab sebagai sebab terjadinya kenakalan anak. Nasih Ulwan secra terperinci mengupas secara jelas beberapa penyebab kenakalan anak, sebagai berikut:

\section{a. Perselisihan antara bapak dan ibu}

Salah satu faktor terbesar yang menyebabkan terjadinya kenakalan pada anak adalah berlangsungnya suasana ketidak harmonisan antara bapak dan ibu di rumah. ${ }^{12}$ Menghadapi dan merasakan atmosfer suasana keluarga yang tidak kondusif tersebut, mengakibatkan anak tidak betah tinggal di rumah dan menghabiskan waktunya di luar rumah. Seandainya interaksi dan pergaulan anak dengan temannya di luar rumah tersebut salah, misalnya anak tersebut bergaul dengan teman yang nakal dan jahat, maka secara perlahan anak akan terseret pada kejahatan dan kenakalan.

Kualitas kehidupan keluarga memainkan peranan besar dalam membentuk kepribadian anak yang nakal. Dalam perspektif pendidikan islam, keluarga merupakan lingkungan pertama bagi anak. Di lingkungan ini anak pertama kali mendapatkan pengaruh. Bapak dan ibu di dalam keluarga bertugas sebagai pendidik. Jika tugas-tugas mendidik dan tugas memberikan pengaruh yang dijalankan oleh bapak dan ibu terhadap anaknya tidak berfungsi, maka akan menghasilkan pengaruh yang buruk terhadap anak.

Tugas dasar orang tua yang tidak berfungsi tersebut bisa berbentuk tidak mampu menciptakan suasana keluarga yang harmonis dan perselisihan antara bapak-ibu. Kejadian seperti ini sebetulnya akan mendatangkan rasa takut bercampur sedih pada diri anak, sehingga menjadi beban bagi jiwanya dan membuatnya bingung. Dengan kondisi internal keluarga yang demikian, besar kemungkinan anak akan melampiaskan kondisi jiwanya tersebut pada hal-hal yang negatif.

\section{b. Lingkungan dan teman yang buruk}

Lingkungan dan teman yang buruk bisa menjadi sebab terjadinya kenakalan anak. Namun Nasih Ulwan membatasi pada anak yang memiliki kemampuan kognitif rendah, lemah akidah, dan anak yang memiliki akhlak yang fluktuatif. ${ }^{13}$ Oleh karena itu, anak tersebut akan cepat terpengaruh oleh kebiasaan buruk dari teman dan lingkungannya. Bahkan yang lebih buruk lagi, ketika anak terlalu lama berinteraksi dan berbaur dengan lingkungan dan teman yang buruk tersebut, maka segala bentuk kejahatan, keburukan dan kenakalan akan menjadi sebuah kebiasaan. Dengan demikian sulit kiranya memperbaiki dan menyelamatkan anak tersebut.

Pendapat Nasih Ulwan tersebut sangat beralasan, karena pengaruh teman dan lingkungan terhadap anak sangat besar, termasuk di dalamnya pengaruh positif dan negatif. Sedangkan yang dikhawatirkan adalah pengaruh buruk teman dan lingkungan terhadap anak. Secara fitrah anak

${ }^{12}$ Abdullah Nasih Ulwan, Tarbiyat al-Aulad fi al-Islam (Suriah: Daar al-Salaam, 1992), Hlm. 122

${ }^{13}$ Abdullah Nasih Ulwan, Tarbiyat al-Aulad fi al-Islam, Hlm. 133 
ISTIGHNA, Vol. 2, No 2, Juli 2019 P-ISSN 1979-2824 E-ISSN 2655-8459

Homepage: http://e-journal.stit-islamic-village.ac.id/index.php/istighna

Minggusta Juliadarma

Pencegahan Kenakalan Anak Menurut Abdullah Nasih Ulwan

akan mencoba beradaptasi dengan lingkungannya tanpa mempedulikan hal itu baik atau buruk.

Orang tua seharusnya menyadari bahwa pada saat tertentu anak tidak hanya bergaul terbatas di lingkungan keluarga saja, tetapi menuntut pergaulan yang lebih luas. Interaksi anak dengan teman sebaya merupakan konsekuensi logissebagai respon anak dalam pengembangan interaksi sosial.

Dalam pendidikan islam, diantara tugas orang tua dalam memantau perkembangan sosial anak adalah mengawasi, membimbing dan mengarahkan anak untuk selektif dalam memilih teman dan berbaur dengan lingkungan sosial lainnya. Ketika orang tua abai terhadap fungsinya itu, maka anak tidak terkontrol pergaulan sosialnya, sehingga segala pengaruh yang diserap oleh anak sebagai hasil interkasinya tersebut teraplikasi dalam bentuk perilaku buruk.

\section{c. Perceraian Orang Tua}

Faktor mendasar lainnya yang menyebabkan terjadinya kenakalan pada anak adalah terjadinya perceraian orang tua. ${ }^{14}$ Akibat yang ditimbulkan dari perceraian adalah terpisahnya anak dari orang tuanya dan tersia-siakannya anak akan kasih saying orang tua. Lebih parah lagi, ketika orang tuanya telah bercerai dan memutuskan menikah lagi dengan orang lain, maka anak akan semakin merasa tersingkirkan keberadaannya. Maka hal itu akan mendorong anak melakukan kenakalan dan kejahatan.

Telah ditegaskan oleh para ahli pendidikan islam bahwa pengalamanpengalaman social yang benar dan berbagai bentuk interaksi yang dilakukan anak dalam keluarga, memiliki peran penting dalam pembentukan dan pembinaan kepribadian dan perilakunya. Perceraian adalah momok yang menakutkan yang bisa saja mengancam keluarga manapun. Perceraian dalam pendidikan Islam diidentikkan dengan perbuatan buruk yang dihalalkan, karena meskipun secara hukum islam bercerai itu boleh, namun sangat dibenci Allah SWT.

\section{d. Kemiskinan}

Latar belakang keluarga yang miskin memiliki dampak besar yang menyebabkan anak berinisiatif meninggalkan rumah untuk mencari sendiri bekal untuk hidupnya. Dengan demikian ia akan mudah diperdaya oleh keadaan yang mendesak dengan menggunakan segala cara sebagai penopang hidupnya, bahkan cara yang jelek dapat ditempuhnya. ${ }^{15}$

Dalam Islam, salah satu dasar pembinaan keluarga adalah menganjurkan menikah bagi orang yang telah memiliki penghasilan untuk menafkahi istri dan anaknya. Karena bagaimanapun penghasilan suami sebagai penanggung jawab keluarga sangat menunjang bagi terwujudnya kebahagiaan dan kesejahteraan financial keluarga. Anjuran ini bertujuan untuk mengantisapasi permasalahan-permasalahan yang akan timbul di kemudian hari setelah menikah yang berkaitan dengan permasalahan pemenuhan nafkah keluarga.

${ }^{14}$ Abdullah Nasih Ulwan, Tarbiyat al-Aulad fi al-Islam, Hlm. 123

${ }^{15}$ Abdullah Nasih Ulwan, Tarbiyat al-Aulad fi al-Islam, Hlm. 122 
ISTIGHNA, Vol. 2, No 2, Juli 2019 P-ISSN 1979-2824 E-ISSN 2655-8459

Homepage: http://e-journal.stit-islamic-village.ac.id/index.php/istighna

Minggusta Juliadarma
Pencegahan Kenakalan Anak Menurut Abdullah Nasih Ulwan

Banyak sekali permasalahan dalam keluarga yang bersumber dari tidak terpanuhinya ekonomi keluarga. Salah satunya dapat menimbulkan terjadinya kenakalan anak sebagai dampak ketidak mampuan orang tua dalam memenuhi nafkah fisik anaknya.

\section{e. Perlakuan buruk dari orang tua}

Seorang anak ketika diperlakukan kasar oleh orang tuanya atau para pendidiknya, seperti dididik dengan cara dipukul, berkata yang pedas, dan menghina, maka akan menimbulkan reaksi balik yang nampak pada perangainya. Hal ini berdampak pada munculnya rasa takut dan kekhawatiran pada tindakan dan perilakunya. Kemudian bisa berimbas pada anak untuk pergi meninggalkan rumah sebagai langkah penyelamatan diri. ${ }^{16}$

Bahkan lebih parah lagi, terkadang akan menimbulkan tindakan bunuh diri atau membunuh kedua orang tuanya. Tidak mengherankan keadaan seperti ini dapat membentuknya menjadi orang yang jahat dan menyimpang di masyarakat. Jadi perlakuan-perlakuan kasar dari orang tua merupakan cerminan dari perilaku anak yang dapat dicontohnya.

\section{f. Penyalahgunaan sarana media massa}

Interaksi dan aktivitas anak terhadap penggunaan media massa memiliki dampak terhadap terjadinya kenakalan anak. Bentuk penyalahgunaan media massa yang lazim dilakukan oleh anak antara lain, anak menonton film porno, film criminal, membaca cerita cabul, dan mendengarkan suara/desahan wanita yang menjurus pada aktivitas seksual. Tidak diragukan lagi, bahwa kondisi yang rusak seperti itu memiliki pengaruh besar pada diri anak. Terlebih lagi pada anak yang berada pada usia pubertas. $^{17}$

Sebenarnya pandangan Nasih Ulwan ini bertentangan dengan konsep yang ditawarkan oleh pendidikan islam. Jika Nasih Ulwan antipati terhadap keberadaan media massa terkait dengan pemanfaatannya oleh anak, pendidikan islam justru menganjurkan pemanfaatan media massa oleh anak. Kesamaannya adalah keduanya sama-sama memberikan perhatian lebih terhadap materi-materi orang dewasa yang sebaiknya dihindarkan dari pengamatan anak.

\section{g. Orang tua tidak memperhatikan pendidikan anak}

Orang tua yang abai akan pendidikan anaknya menjadi salah satu sebab terjadinya kenakalan anak. Itulah resiko yang terjadi akibat orang tua yang lebih memperhatikan karirnya masing-masing tanpa memperhatikan perkembangan pendidikan anak. Mereka luput memantau perilaku anak mereka, sehingga anak terperosok pada pendidikan yang salah. Anak merasa dirinya terasing dan tidak terurus, sehingga pelariannya adalah dengan mencari jalan apa saja yang membuatnya merasa diperhatikan. ${ }^{18}$

\footnotetext{
${ }^{16}$ Abdullah Nasih Ulwan, Tarbiyat al-Aulad fi al-Islam, Hlm. 135

${ }^{17}$ Abdullah Nasih Ulwan, Hukm al-Islam Fi Wasaailil I'laam (Suriah: Daar al-Salaam, 2001), HIm. 4

${ }^{18}$ Abdullah Nasih Ulwan, Tarbiyat al-Aulad fi al-Islam, Hlm. 129
} 
ISTIGHNA, Vol. 2, No 2, Juli 2019 P-ISSN 1979-2824 E-ISSN 2655-8459

Homepage: http://e-journal.stit-islamic-village.ac.id/index.php/istighna

\section{Minggusta Juliadarma \\ Pencegahan Kenakalan Anak Menurut Abdullah Nasih Ulwan}

\section{h. Penyalahgunaan waktu luang}

Fitrah anak yang mudah tertarik pada permainan adalah sesuatu yang harus diwaspadai oleh orang tua. Semua tergantung pada para pendidik dan orang tua dalam memanfaatkan fitrah anak tersebut untuk dibawa pada halhal yang positif atau negatif dengan segala konsekuensinya.

Pendidikan islam memandang bermain merupakan aktivitas sosial, karena di dalamnya anak dapat berinteraksi dengan kawannya. Di samping itu, bermain juga merupakan bagian dari aktivitas yang dapat membantu anak yang senang menyendiri (introvert) dan mementingkan diri sendiri untuk mulai membangun hubungan sosial bersama anak-anak lainnya. Perilaku anak juga dapat dipelajari melalui aktivitas bermain.

4. Pencegahan Kenakalan Anak Menurut Abdullah Nasih Ulwan

a. Pengawasan Terhadap Dampak Negatif Media Massa Pada Anak Dengan Metode Penanaman Prinsip-prinsip Islam

Menurut Nasih Ulwan media massa dapat berdampak positif dan negatif. Maka dia merinci media apa saja yang dapat dikategorikan sebagai media massa yang memiliki dampak, yaitu radio, televisi, bioskop, Koran, majalah, dan panggung kesenian.

Media massa di atas dapat berdampak positif jika digunakan untuk kebaikan, seperti untuk penyebaran ilmu, penguatan akidah, perbaikan akhlak, dan dapat juga menjadi sarana mendidik anak yang menuntun mereka pada kemulyaan dan kehormatan. Sejauh penggunaan tersebut, media massa diperbolehkan penggunaannya, pemanfaatannya, mendapatkannya, dan memperhatikannya. ${ }^{19}$

Sebaliknya, media massa akan berdampak negatif jika dipergunakan untuk mendatangkan penyimpangan dan kerusakan, seperti menyebarkan berita yang tidak benar, mempengaruhi anak-anak pada prinsip-prinsip selain islam, menampilkan perbuatan yang tidak baik, dan nasihat-nasihat yang menyesatkan. Selama penggunaannya seperti itu, maka media masssa menjadi alat perusak generasi muslim.

Terkait dengan fenomena ini, Nasih Ulwan menawarkan solusi dengan mengupayakan dan menjalankan prinsip-prinsip Islam di dalam mengarahkan, mendidik, dan menunauikan hak dan kewajiban. Prinsipprinsip islam ini membutuhkan peran aktif orang tua, guru, dan pemangku tanggung jawab pendidikan lainnya untuk konsisten memahami dan melaksanakannya dalam kehidupan sehari-hari.

Diantara prinsip tersebut yaitu melindungi dirinya dan keluarganya dari setiap sesuatu yang dapat menyebabkan azab dari Allah SWT, prinsip ini memiliki landasan yang kuat dari Q.S. al-Tahrim 6; "Wahai orang-orang yang beriman peliharalah dirimu dan keluargamu dari api neraka...”.

Prinsip lainnya adalah dengan melatih tanggung jawab kepada semua pihak yang memiliki hak untuk diarahkan dan dididik. Tujuannya agar mereka dapat mengaplikasikan tanggung jawab dan amanah pada setiap keadaan dan situasi. Prinsip ini berlandaskan hadits Rasul SAW; "Seorang

${ }^{19}$ Abdullah Nasih Ulwan, Hukm al-Islam Fi Wasaailil I'laam (Suriah: Daar al-Salaam, 2001), Hlm. 4 
ISTIGHNA, Vol. 2, No 2, Juli 2019 P-ISSN 1979-2824 E-ISSN 2655-8459

Homepage: http://e-journal.stit-islamic-village.ac.id/index.php/istighna

Minggusta Juliadarma

Pencegahan Kenakalan Anak Menurut Abdullah Nasih Ulwan

laki-laki itu pemimpin dalam keluarganya dan bertanggung jawab atas kepemimpinannya..." (HR. Muslim).

Prinsip berikutnya adalah menghilangkan bahaya dari segala sesuatu yang dapat mengantarkan pada penyimpangan akidah dan akhlak mereka. Hal ini berlandaskan hadits; "Tidak boleh melakukan tindakan berbahaya dan membahayakan orang lain" (HR. Malik).

Semua metode tersebut merupakan metode yang dijalankan melalui penanaman prinsip-prinsip islam dalam keluarga. Disana terdapat peran penting orang tua dalam proses mendidik anaknya dalam keluarga. Lebih spesifik lagi, menurut metode tersebut orang tua dituntut memiliki peran sebagai pengawas, pemberi peringatan, pendidik, pemberi pengarahan, pemimpin bagi anaknya, serta menjaga anaknya dari segala bahaya yang ditimbulkan oleh media massa saat ini sehingga dampak negatif dari pemanfaatannya dapat dieliminir. Secara keseluruhan, Nasih Ulwan antipati terhadap media massa, khususnya jika penggunaannya disalahgunakan, baik oleh penggunanya maupun dari pihak-pihak yang berkepentingan, maka dia mengkritik keras tindakan tersebut.

\section{b. Peran Aktif Orang Tua Dalam Mengaplikasikan Tahapan Pendidikan Seksual Bagi Anak}

Salah satu aspek mendidik anak yang perlu menjadi perhatian orang tua adalah bagaimana menghindarkan anak dari segala sesuatu yang mengarah pada kerusakan mental dan perilakunya dari dampak buruk sesuatu yang sebenarnya bukan wilayah perkembangannya. Contoh konkretnya adalah permasalahan seksual. Tentu saja wilayah ini merupakan wilayah yang tidak selayaknya dikonsumsi oleh anak dan wilayah yang tidak sepantasnya digeluti oleh anak, semua sepakat ini adalah wilayah orang dewasa.

Berbeda dengan stigma yang melekat pada pendidikan seksual di atas, Nasih Ulwan bahkan menganjurkan orang tua untuk dapat memperkenalkan dan mengaplikasikan pendidikan seksual dini pada anak. Karena menurutnya, definisi pendidikan seksual adalah suatu proses memberikan penjagaan dan penjelasan secara komprehensif pada anak ketika ia sudah memahami hal-hal yang berkaitan dengan seks dan pernikahan. Sehingga saat anak telah memasuki usia baligh dan memahami segala hal yang berkaitan dengan hidupnya, maka dia akan siap dan telah mengetahui akan perkara halal dan haram, mengetahui dan membiasakan dengan kebiasaan yang islami, tidak secara mudah mengumbar syahwatnya dan selektif dalam segala hal.20

Kemudian Nasih Ulwan memetakan pendidikan seksual pada anak melalui fase-fase yang harus diperhatikan oleh orang tua, yaitu usia 7-10 tahun dinamakan usia tamyiz, di usia ini anak diajarkan adab meminta izin dan adab memandang. Maksud dari adab meminta izin adalah orang tua mengajarkan dan membiasakan anak agar selalu meminta izin ketika akan memasuki kamar orang tuanya. Tujuannya untuk menghindarkan anak dari

\footnotetext{
${ }^{20}$ Abdullah Nasih Ulwan, Mas'uliyat al-Tarbiyat al-Jinsiyyah (Suriah: Daar al-Salaam, 2010),
} Hlm. 5 
ISTIGHNA, Vol. 2, No 2, Juli 2019 P-ISSN 1979-2824 E-ISSN 2655-8459

Homepage: http://e-journal.stit-islamic-village.ac.id/index.php/istighna

Minggusta Juliadarma

Pencegahan Kenakalan Anak Menurut Abdullah Nasih Ulwan

pemandangan-pemandangan yang belum selayaknya mereka lihat dan dengar terkait aktivitas kedua orang tuanya di kamar.

Pada usia ini anak juga diajarkan adab memandang. Maksudnya adalah mengajarkan adab memandang lawan jenis kepada anak saat masih dalam usia anak-anak akhir. Hal ini bertujuan agar anak mengetahui siapa yang halal untuk dipandang dan siapa yang haram untuk dipandang. Sebab dalam pandangan itu terdapat kebaikan untuk dirinya dan memupuk kebaikan akhlaknya saat ia mencapai usia baligh dan dewasa kelak.

Usia 10-14 tahun dinamakan usia murahaqat, yaitu usia anak yang hampir mendekati baligh. Pada usia ini anak dijauhkan dari segala hal yang mengarah pada seks. Karena hal itu dapat merangsang syahwat dan merusak akhlaknya. Nasih Ulwan memaparkan tanggungjawab orang tua dalam melakukan pengawasan internal dan eksternal. Diantara bentuk pengawasan internal orang tua adalah orang tua harus melarang anaknya yang sudah mencapai usia remaja masuk ke ruangan wanita yang bukan mahramnya, memisahkan tempat tidur anak bersama saudaranya ketika sudah mencapai usia 10 tahun, mengajarkan pada anak etika memandang sejak masa pertumbuhannya, mengontrol penggunaan televisi, mengawasi anak dengan sesekali memeriksa kamarnya karena dikhawatirkan menyimpan sesuatu yang tidak baik, dan tidak memberikan kesempatan bagi anaknya untuk berpacaran di usia ini.

Selanjutnya tanggungjawab pengawasan eksternal adalah pengawasan orang tua terhadap media-media yang dapat merusak perilaku dan merangsang keinginan seksual pada anak, seperti busana wanita yang memperlihatkan auratnya, rumah pelacuran, poster dan papan iklan yang mengumbar aurat, teman yang buruk, dan ikhtilat (bercampurnya laki-laki dan wanita dalam satu ruangan).

Usia 14-16 tahun dinamakan usia baligh. Pada usia ini anak diajarkan tentang aturan-aturan fikih saat mereka telah bermimpi, sebagai tanda mereka sudah memasuki usia baligh. Selain itu juga menerangkan adabadab berhubungan seksual saat ia sudah siap untuk menikah.

Usia setelah baligh dinamakan usia pemuda. Pada usia ini meskipun secara fisik dan mental sudah bisa berusaha berpikir secara rasional dan obyektif, namun masih lemah dari aspek keteguhan hati, sering ragu-ragu dan sering pula tergesa-gesa dalam mengambil keputusan. Oleh karena itu, peran orang tua masih tetap dibutuhkan untuk mengarahkan dan mendidik mereka.

Pada fase ini anak diajarkan tentang adab menjaga kehormatan dan menahan diri ketika ia belum mampu untuk menikah. Metode yang paling ampuh dalam menjaga kehormatan seorang anak adalah dengan jalan menikah, meskipun itu dilakukan dengan cara pernikahan dini. Bagi seorang yang belum mampu menikah, maka cara menahan diri adalah dengan jalan menjaga kemaluan dan mengekang nafsu amarah yang selalu mendorong kepada perbuatan jelek. 


\section{Minggusta Juliadarma \\ Pencegahan Kenakalan Anak Menurut Abdullah Nasih Ulwan}

\section{c. Menciptakan Hubungan yang Harmonis Antara Bapak dan Ibu dengan Pemenuhan Hak dan Kewajiban}

Pendidikan islam sangat memperhatikan pendidikan anak dalam keluarga, karena lingkungan keluarga merupakan lingkungan terkecil dalam wilayah interaksi sosial kemasyarakatan. Namun di lingkungan keluarga inilah yang menjadi penentu terhadap pendidikan dan perilaku anak. Dalam keluarga tercipta interaksi antar anggota keluarga, bapak, ibu, dan anak. Melalui interaksi inilah secara tidak langsung akan tercipta karakter anak. Jika anak dididik di lingkungan keluarga yang harmonis, maka itu akan berimplikasi pada pendidikan dan perilaku anak yang baik.

Dua faktor utama penyebab terjadinya kenakalan dan penyimpangan pada anak adalah terjadinya pertengkaran dan perceraian orang tua. Dua kejadian tersebut sam-sama dipicu oleh suasana keluarga yang tidak kondusif yang menyebabkan anak tidak betah tinggal di rumah dan menghabiskan waktunya di luar rumah sehingga pergaulannya tidak terkontrol dan liar.

Berkenaan dengan fenomena tersebut, Nasih Ulwan memberikan solusi berbeda pada berbagai permasalahan keluarga yang tidak menguntungkan bagi anak. Untuk problematika perselisihan antara bapak dan ibu, solusi yang ditawarkan cukup unik, yaitu dengan melakukan upaya preventif sejak sebelum menikah, dengan memperhatikan prinsip-prinsip islam dalam memilih pasangan hidup sebelum memutuskan untuk menikah dengan seseorang.

Sedangkan untuk problematika perceraian, Nasih ulwan lebih mengedepankan upaya rekonsiliasi. Metodenya adalah dengan upaya dari kedua belah pihak untuk saling memenuhi hak dan kewajiban masingmasing secara proporsional. Hak dan kewajiban itu diantaranya adalah istri mentaati perintah suami, menjaga diri dan harta suaminya, tidak menolak ajakan suami untuk melakukan hubungan badan, suami mempunyai kewajiban menafkahi istrinya, mengedepankan musyawarah tentang perkara rumah tangga, dan tidak selayaknya mengeksplorasi kekurangan pasangannya.

\section{d. Melakukan pengawasan terhadap Tingkah Laku Sosial Anak}

Menurut Nasih Ulwan, pendidikan sosial adalah mengajari anak semenjak kecil untuk berpegang pada etika social yang utama dan dasardasar kejiwaan yang mulia, bersumber dari akidah islam yang abadi dan perasaan keimanan yang tulus. Tujuan pendidikan social ini agar anak dapat tampil di masyarakat sebagai generasi yang mampu berinteraksi social dengan baik, beradab, seimbang, berakal matang, berperilaku dengan bijaksana.

Faktor pertemanan dan pergaulan anak dalam lingkungan mereka sudah selayaknya mendapat perhatian serius. Bahwa jika anak tidak selektif dalam bergaul dan membaur dengan temannya, maka dia akan ikut terbawa arus negatif dari lingkungannya. Ditambah lagi dari aspek psikologis, masa anak adalah masa yang paling cepat untuk menirukan segala apa yang menarik perhatian mereka, sehingga bisa saja hal itu malah menjadi kebiasaannya. Celakanya, jika apa yang ditirukannya adalah sesuatu yang tidak baik, maka 
ISTIGHNA, Vol. 2, No 2, Juli 2019 P-ISSN 1979-2824 E-ISSN 2655-8459

Homepage: http://e-journal.stit-islamic-village.ac.id/index.php/istighna

Minggusta Juliadarma

Pencegahan Kenakalan Anak Menurut Abdullah Nasih Ulwan

akan terbentuklah kebiasaan dan perilaku yang tidak baik pula. Jika sudah menjadi kebiasaan, maka akan sulit bagi orang tua dan pendidik untuk merubahnya.

Berdasarkan elaborasi di atas, Nasih Ulwan mengarahkan pola pendidikan yang islami untuk orang tua dan pendidik dalam memberikan pengawasan yang ketat terhadap anak dan tidak abai terhadap interaksinya dengan lingkungan sosialnya, khususnya ketika anak memasuki usia tamyiz dan puber.

Metode pengawasan orang tua terhadap tingkah laku sosial anak menurut Nasih Ulwan ini selaras dengan studi klasik tentang hubungan orang tua dan anak yang dicetuskan oleh Diana Baumrind, yaitu model pengasuhan otoritatif (authoritative parenting). Model pengasuhan ini merupakan salah satu model pengasuhan yang memperlihatkan pengawasan ekstra ketat terhadap tingkah laku anak, tetapi mereka juga bersikap responsif, menghargai dan menghormati pemikiran, perasaan, serta mengikutsertakan anak dalam pengambilan keputusan. ${ }^{21}$

\section{e. Jaminan Negara Terhadap Kesejahteraan Ekonomi Warganya}

Nasih Ulwan berpendapat bahwa terdapat korelasi Negara dengan timbulnya kenakalan pada anak. Landasan teorinya adalah islam mewajibkan kepada ibu dan bapak untuk mendidik anaknya dan tidak menelantarkan mereka untuk diberi nafkah. Namun jika latar belakang ekonomi ibu dan bapaknya tersebut tidak memungkinkan untuk menafkahi anaknya, maka fenomena yang terjadi adalah anak akan berinteraksi di luar rumah untuk menafkahi dirinya sendiri. Tidak ada yang menjamin kehidupan di luar rumah akan berjalan baik. Peluang terjadinya penyimpangan anak, pengaruh dari lingkungan yang buruk, dan teman yang buruk akan besar pengaruhnya terhadap timbulnya kenakalan anak. Disinilah letak tanggung jawab Negara untuk menanggulangi peluangpeluang terjadinya kenakalan anak yang dilatarbelakangi dengan rendahnya kemampuan ekonomi warganya.

Jika kita memperhatikan dengan seksama, gagasan Nasih Ulwan terkait dengan tanggung jawab Negara terhadap kesejahteraan warganya yang mengikutsertakan peran masyarakat, maka gagasan itu sebenarnya identik sekali dengan gagasan yang dianut oleh salah satu gerakan populer di Mesir yang dipelopori oleh Hassan al-Banna, yaitu Ikhwan al-Muslimin. Oragnisasi ini menyatakan bahwa Negara berkewajiban menggunakan kekayaan rakyat dengan sebaik-baiknya, memungut dengan cara yang baik dan menggunakannya dengan cara yang baik pula, serta adil dalam menggalinya. ${ }^{22}$

Mengaitkan pemikiran Nasih Ulwan dengan gagasan Ikhwan alMuslimin diperlukan, karena beliau pernah bergabung dengan organisasi tersebut saat kuliah di Mesir. Khusus dalam aspek ini ternyata keduanya memiliki kedekatan pemikiran yang sama.

\footnotetext{
${ }^{21}$ Desmita, Psikologi Perkembangan (Bandung: Remaja Rosdakarya, 2009), Hlm. 144-145

${ }^{22}$ Anis Matta, Risalah Pergerakan Ikhwanul Muslimin (Solo: Era Intermedia, 2000), Hlm. 328
} 
ISTIGHNA, Vol. 2, No 2, Juli 2019 P-ISSN 1979-2824 E-ISSN 2655-8459

Homepage: http://e-journal.stit-islamic-village.ac.id/index.php/istighna

Minggusta Juliadarma
Pencegahan Kenakalan Anak Menurut Abdullah Nasih Ulwan

\section{f. Orang Tua Berlaku Lemah Lembut dan Menghindari Perlakuan yang Buruk terhadap Anak}

Fitrahnya hati orang tua diliputi dengan rasa cinta, tumbuh perasaan kejiwaan, rasa rindu, kepedulian mendidik, bersabar, menjaga dan kasih sayang terhadap anak. Fitrah tersebut kemudian terimplementasikan dalam bentuk tanggungjawab orang tua dalam memenuhi hak-hak anak. ${ }^{23}$

Dalam hal pemenuhan orang tua terhadap hak anak inilah sebenarnya yang menjadi permasalahan. Karena tidak jarang orang tua bertindak secara berlebihan terhadap anaknya, bahkan cenderung kasar. Perlakuan buruk inilah secara tidak langsung dapat berimplikasi buruk pada perkembangan moral dan perilaku mereka.

Perlakuan buruk orang tua kepada anaknya secara garis besar akan berdampak internal dan eksternal pada diri anak. Dampak internal maksudnya dampak perlakuan buruk orang tua berdampak pada perkembangan psikologis anak, seperti perasaan takut dan khawatir. Sedangkan maksud dari dampak eksternal adalah dampak pada perkembangan sosialnya, seperti anak berbuat kriminal dan perbuatan menyimpang lainnya di tengah masyarakat.

Dalam konteks legal formal, The Universal Declaration of Human Rights (UDHR) pasal 25 ayat 2 menegaskan, "Ibu-ibu dan anak-anak berhak memperoleh perawatan dan bantuan khusus, semua anak yang dilahirkan di dalam maupun di luar pernikahan harus memperoleh perlindungan sosial yang sama. $^{24}$

Terkait dengan pemberian hukuman pada anak yang melakukan kesalahan, Nasih Ulwan berpendapat hendaknya hukuman tersebut mengandung perbaikan dan pendidikan. Seandainya dengan cara yang lembut telah memberikan manfaat, maka cukup dengan nasihat. Seorang pendidik tidak boleh mudah terprovokasi pada pola kekerasan dalam mendidik anak. Namun, jika pola ancaman dan kekerasan lebih memberikan manfaat, maka tetap tidak boleh sampai ada pemukulan. Apabila semua pola/cara telah ditempuh, baik kelembutan maupun kekerasan, tapi belum membuahkan hasil, maka tidak mengapa melakukan pemukulan tanpa menyakiti.

Tahapan-tahapan dalam pemberian hukuman ini dilakukan ketika usia mereka masih anak-anak dan puber. Apabila telah memasuki usia remaja dan menuju masa dewasa, maka cara pemberian hukumannnya berbeda. Nasih Ulwan berpendapat ketika orang tua telah menerapkan cara nasihat dan tidak memberi pengaruh, maka hukuman yang diberikan orang tua pada anaknya yang telah sampai pada usia remaja adalah dengan metode hijr. Metode ini maksudnya orang tua sengaja tidak berbicara, tidak menggubris, dan tidak bergaul dengan anaknya sampai pada batas waktu tertentu.

${ }^{23}$ Abdullah Nasih Ulwan, Ilaa Kulli Abin Ghayur Yu'min Billah (Suriah: Daar al-Salaam, 1992), Hlm. 6

24 Ahmad Kosasih, HAM Dalam Perspektif Islam; Menyingkap Persamaan dan Perbedaan antara Islam dan Barat (Jakarta: Salemba Diniyah, 2003), Hlm. 73 
ISTIGHNA, Vol. 2, No 2, Juli 2019 P-ISSN 1979-2824 E-ISSN 2655-8459

Homepage: http://e-journal.stit-islamic-village.ac.id/index.php/istighna

\section{Minggusta Juliadarma \\ Pencegahan Kenakalan Anak Menurut Abdullah Nasih Ulwan}

\section{g. Mengisi Waktu Luang Anak Dengan Sarana-sarana 'Amaliyat yang Bermanfaat}

Upaya orang tua dalam membiasakan anak untuk memanfaatkan waktu secara baik, maka akan membawa anak tersebut ke arah kegiatan yang positif. Terlebih lagi anak tidak memiliki aktivitas rutin layaknya orang dewasa. Tentu anak menyisakan lebih banyak waktu luangnya. Inilah sebenarnya yang menjadi kebutuhan, yaitu adanya pembiasaan manajemen waktu luang secara bijaksana oleh anak.

Nasih Ulwan memberikan solusi dalam pemanfaatan waktu luang anak yang dapat dimaksimalkan oleh orang tua, yaitu mengisi waktu luang anak dengan sarana-sarana 'amaliyat yang bermanfaat. Hal ini sekaligus dapat meminimalisisr peluang bagi anak untuk melakukan hal-hal yang tidak bermanfaat bagi dirinya. Saran-sarana tersebut diantaranya sarana pembiasaan ibadah, misalnya membiasakan anak melaksanakan ibadah shalat lima kali sehari khususnya saat anak telah menginjak usia tujuh tahun.

Sarana penguatan fisik juga dapat dimaksimalkan oleh orang tua pada anaknya untuk mengisi waktu luangnya, misalnya olahraga. Aktivitas jasmani ini penting untuk dibiasakan agar dapat mengembangan kemampuan psikomotorik anak dan bermanfaat bagi tubuh dan kesehatan anak.

Sarana lainnya adalah sarana rekreasi dan belajar bersama. Meski demikian jenis rekreasi harus dipilih secara bijak, karena rekreasi dapat pula memberikan pengaruh negatif pada anak. Ada perbedaan antara rekreasi dengan hiburan, rekreasi memiliki kecenderungan untuk menguatkan dan membina, sebaliknya hiburan dicari untuk mendapatkan kesenangan secara berlebihan. ${ }^{25}$

\section{h. Kerja Sama Orang Tua Dalam Memperhatikan Pendidikan Anaknya}

Berkaitan dengan ini Nasih Ulwan sangat concern terhadap kelengahan orang tua akan pendidikan anaknya, karena hal itu benar-benar dapat menjadi salah satu sebab timbulnya kenakalan anak. Dalam hal ini Nasih Ulwan memiliki kecenderungan untuk menempatkan ibu sebagai pihak yang paling bertanggung jawab akan tugas mendidik, mengarahkan, memelihara, dan memperbaiki jiwa anak, lebih dari tanggungjawab bapak pada anaknya. $^{26}$

Bila diperhatikan sepintas, pendapat tersebut dirasa diskriminatif dengan mengkerdilkan peran dan tanggungjawab bapak pada anaknya. Namun argument tersebut lebih didasarkan pada ikatan emosional seorang ibu terhadap anaknya yang jauh melebihi ikatan emosional anak dengan bapaknya. Hal itu wajar, karena ibulah yang menyusui anaknya dan senantiasa mendampingi anak sejak dilahirkan hingga tumbuh dewasa. Berbeda dengan bapak yang hanya memiliki kontribusi secara tidak

\footnotetext{
${ }^{25}$ Sarumpet, Pedoman Rumah Tangga (Bandung: Indonesia Publishing House, 2001), Hlm. 207 48

${ }^{26}$ Abdullah Nasih Ulwan, Al-Takaf al-Ijtima'i fi al-islam (Suriah: Daar al-Salaam, 2007), Hlm.
} 
ISTIGHNA, Vol. 2, No 2, Juli 2019 P-ISSN 1979-2824 E-ISSN 2655-8459

Homepage: http://e-journal.stit-islamic-village.ac.id/index.php/istighna

\section{Minggusta Juliadarma \\ Pencegahan Kenakalan Anak Menurut Abdullah Nasih Ulwan}

langsung pada anak, yaitu mencari nafkah dan penghasilan di luar rumah. Perbedaan peran inilah yang melatarbelakangi argementasi Nasih Ulwan di atas.

Proporsi pembagian tugas yang jelas antara bapak dan ibu inilah yang dapat menghindarkan anak terlantar dari pendidikannya dan menghindari pengaruh buruk pendidikan yang salah. Diperlukan kerja sama antara bapak dan ibu dalam memperhatikan pendidikan anaknya, metodenya adalah dengan pengaplikasian pembagian tugas antara keduanya. Seorang ibu tentunya akan bekerja sesuai dengan kekhususan dan tabiatnya, yaitu mengatur sebaik mungkin urusan kerumahtanggaan dan mendidik anak.

Demikian juga seorang bapak, ia bekerja sesuai dengan kekhususan dan tabiat kelaki-lakiannya, yaitu dengan bekerja menghidupi keluarganya, mengerjakan pekerjaan yang berat, serta melindungi keluarga dari bahaya dan musibah yang bisa datang setiap saa. ${ }^{27}$

Demikianlah pemikiran Nasih Ulwan tentang pencegahan kenakalan anak. Berdasarkan penelitian yang telah dielaborasi dari berbagai karyanya, terdapat delapan cara pencegahan kenakalan anak. Kedelapan cara pencegahan tersebut sangat berkaitan erat dengan sebab-sebab terjadinya kenakalan anak, sehingga tercipta dan timbul bentuk-bentuk kenakalan dan perilaku yang menyimpang pada anak.

\section{KESIMPULAN}

Konsep pencegahan kenakalan anak menurut Nasih Ulwan dalam berbagai karya tulisnya merupakan sebuah konsep tindakan preventif yang dapat menekan timbulnya kenakalan dan penyimpangan perilaku pada anak. Hasil elaborasi mengenai bentuk kenakalan anak antara lain: interaksi anak dengan hal-hal yang berbau pornografi, membunuh, mencuri, berakhlak buruk, dan akidah yang lemah.

Sedangkan sebab-sebab terjadinya kenakalan anak diantaranya: perselisihan antara bapak dan ibu, lingkungan dan teman yang buruk, perceraian orang tua, kemiskinan keluarga, perlakuan yang buruk dari orang tua, penyalahgunaan sarana media massa, orang tua tidak memperhatikan pendidikan anak, dan penyalahgunaan waktu luang anak.

Metode yang dapat dimaksimalkan untuk mencegah terjadinya kenakalan pada anak yaitu: pengawasan terhadap dampak negatif media massa pada anak dengan metode penanaman prinsip-prinsip Islam, Peran aktif orang tua dalam mengaplikasikan tahapan pendidikan seksual bagi anak, Menciptakan hubungan yang harmonis antara bapak dan ibu dengan pemenuhan hak dan kewajiban masing-masing, Melakukan pengawasan terhadap tingkah laku sosial anak dengan metode authoritative Parenting, Jaminan negara terhadap kesejahteraan ekonomi warganya, Orang tua berlaku lemah lembut dan menghindari perlakuan yang buruk terhadap anak, Mengisi waktu luang anak dengan sarana-sarana 'amaliyat yang bermanfaat, dan Kerja sama orang tua dalam memperhatikan pendidikan anaknya.

${ }^{27}$ Abdullah Nasih Ulwan, 'Aqabat al-Zawaaj wa Turuq Mu'alijatihaa 'Ala Dhau' al-Islam (Suriah: Daar al-Salaam, 1978), Hlm. 8 
ISTIGHNA, Vol. 2, No 2, Juli 2019 P-ISSN 1979-2824 E-ISSN 2655-8459

Homepage: http://e-journal.stit-islamic-village.ac.id/index.php/istighna

Minggusta Juliadarma

Pencegahan Kenakalan Anak Menurut Abdullah Nasih Ulwan

\section{REFERENSI}

Azzet, Muhaimin. (2010). Buku Pintar Mengatasi Anak Nakal. Yogyakarta: Kata Hati

Desmita. (2009). Psikologi Perkembangan. Bandung: Remaja Rosdakarya

Hadisuprapto, Paulus. (2008). Delinkusensi Anak; Pemahaman dan Penanggulangannya. Malang: Bayu Media Publishing

Kartono, Kartini. (1995). Psikologi Anak (Psikologi Perkembangan).Bandung: Mandar Maju

Kosasih, Ahmad. (2003). HAM Dalam Perspektif Islam; Menyingkap Persamaan dan Perbedaan antara Islam dan Barat. Jakarta: Salemba Diniyah

Matta, Anis. (2000). Risalah Pergerakan Ikhwanul Muslimin. Solo: Era Intermedia

Rahman, Jamaal Abdul. (2005). Tahapan Mendidik Anak; Teladan Rasulullah $S A W$. Bandung: Irsyad Baitus Salam

Sarumpet. (2001). Pedoman Rumah Tangga. Bandung: Indonesia Publishing House

Ulwan, Abdullah Nasih. (1992). Tarbiyat al-Aulad Fi al-Islam. Suriah: Daar alSalaam

\section{Salaam}

(2001). Hukm al-Islam Fi Wasaailil I'laam. Suriah: Daar al(2010). Mas'uliyat al-Tarbiyat al-Jinsiyyat. Suriah: Daar al-

Salaam (2007). al-Takaf al-Ijtima'I Fi al-Islaam. Suriah: Daar al-

Salaam

al-Salaam

(1992). Ilaa Kulli Abin Ghayuur Yu'min Billah. Suriah: Daar (1978). 'Aqabat al-Zawaj wa Turuq Muallajatih 'Ala Daui al-Islaam. Suriah: Daar al-Salaam 